\title{
Socioeconomic development as a determinant of the levels of organochlorine pesticides and PCBs in the inhabitants of Western and Central African countries
}

\author{
Octavio P. Luzardo a,*, Luis D. Boada a , Cristina Carranza ${ }^{\text {b,c }}$, Norberto Ruiz-Suárez a , \\ Luis Alberto Henríquez-Hernández a, Pilar F. Valerón ${ }^{\text {a }}$, Manuel Zumbado ${ }^{\text {a }}$, \\ María Camacho a , José Luis Pérez Arellano ${ }^{\mathrm{b}, \mathrm{c}}$ \\ a Toxicology Unit, Department of Clinical Sciences, Universidad de Las Palmas de Gran Canaria, Las Palmas de Gran Canaria, Spain \\ ${ }^{b}$ Infectious Diseases and Tropical Medicine Unit, Hospital Universitario Insular de Gran Canaria, Las Palmas de Gran Canaria, Spain \\ ${ }^{c}$ Medical Sciences and Surgery Department, Universidad de Las Palmas de Gran Canaria, Las Palmas de Gran Canaria, Spain
}

\section{H I G H L I G H T S}

- Higher levels of organochlorine pesticides in Africans from low-income countries

- Higher levels of PCBs in Africans from high-income countries

- Levels of PCBs are significantly higher in people from West Africa.

- Significant association between implementation of ICT and PCB contamination

- High volume of second-hand electronic equipment is associated with high PCB levels.

\section{A R T I C L E I N F O}

\section{Article history:}

Received 10 June 2014

Received in revised form 31 July 2014

Accepted 31 July 2014

Available online 13 August 2014

Editor: D. Barcelo

\section{Keywords:}

Persistent organic pollutants

Polychlorinated biphenyls

Organochlorine pesticides

Africa

e-waste

Socioeconomic
G R A P H I C A L A B S T R A C T

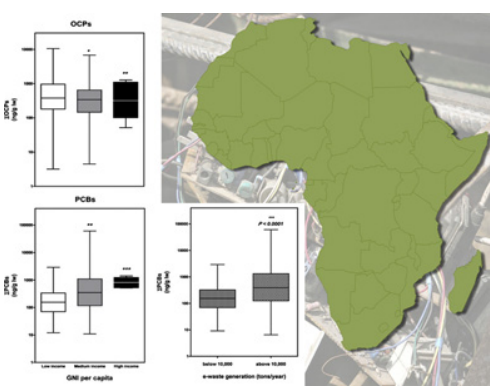

\begin{abstract}
A B S T R A C T
Several studies of environmental samples indicate that the levels of many persistent organic pollutants (POPs) are increasing in Africa, but few studies have been conducted in humans. Simultaneously, many African countries are experiencing a rapid economic growth and implementing information and communication technologies (ICT). These changes have generated high amounts of electronic waste (e-waste) that have not been adequately managed. We tested the hypothesis that the current levels of two main classes of POPs in Western and Central African countries are affected by the degree of socioeconomic development. We measured the levels of 36 POPs in the serum of recent immigrants $(N=575)$ who came from 19 Sub-Saharan countries to the Canary Islands (Spain). We performed statistical analyses on their anthropometric and socioeconomic data. High median levels of POPs were found in the overall sample, with differences among the countries. Organochlorine pesticide $(\mathrm{OCP})$ and polychlorinated biphenyl (PCB) levels increased with age. People from low-income countries had significantly higher OCP levels and much lower PCB levels than those from high-income countries. We found a significant association between the implementation of ICT and PCB contamination. Immigrants from the countries with a high volume of imports of second-hand electronic equipment had higher PCB levels. The economic development of Africa and the e-waste generation have directly affected the levels of POPs. The POP legacies of these African populations most likely are due to the inappropriate management of the POPs' residues.
\end{abstract}

(c) 2014 Elsevier B.V. All rights reserved.

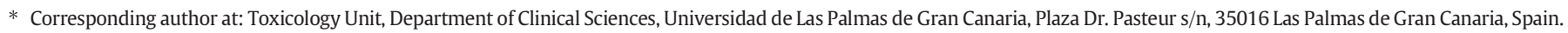
Tel.: + 34928451 424; fax: + 34928451461 .

E-mail address: operez@dcc.ulpgc.es (O.P. Luzardo).
} 


\section{Introduction}

Persistent organic pollutants (POPs) are highly synthetic, lipophilic, persistent, and cumulative substances (Safe, 1990). Human exposure to POPs usually occurs through the ingestion of the fatty parts of animal foods (El-Shahawi et al., 2010). Most POPs come from the production and use of organochlorine compounds, such as organochlorine pesticides (OCPs) and polychlorinated biphenyls (PCBs). Numerous studies have revealed that POPs, individually and in combination, may contribute to the development of severe health problems such as immune suppression, genotoxic effects, or cancer (Bergman et al., 2012; Gioia et al., 2014; Jarvis et al., 2014; Kortenkamp, 2007; Lauby-Secretan et al., 2013; WHO, 2003).

Due to the ban of many of these chemicals worldwide, a considerable number of monitoring studies have found a downward trend in the detection of their concentrations (Kim and Yoon, 2014; Mannetje et al., 2013; Nost et al., 2013; Ryan and Rawn, 2014). However, this steady decline has not been observed in Africa. Although few studies have monitored human contamination in Africa (Gioia et al., 2014), several studies on environmental samples have found that pollution levels in this continent are increasing, instead of declining or remaining stable (Adu-Kumi et al., 2012; Asante et al., 2013; Garrison et al., 2014; Gioia et al., 2014; Klanova et al., 2009; Ndiaye et al., 2012; Ssebugere et al., 2013).

Various reasons seem to underlie the increase in POPs. First, African countries have used (and still use) high amounts of OCPs to eliminate agricultural pests or control disease vectors. Moreover, it has been estimated that approximately 50,000 tons of obsolete pesticides litter the African landscape (World Bank, 2012). Africa has not been a producer and/or major user of PCBs, so their origin seems to be different. However, Africa has been undergoing a rapid transformation of information communication technology (ICT) in recent years (World Bank, 2012), and the bulk import of second-hand electrical and electronic equipment (EEE) from developed countries was established to cover these demands. Moreover, in light of this increased demand, an illegal trade of EEE waste (e-waste) has developed simultaneously, with some estimates of the e-waste generated in developed countries and exported to developing countries being up to 80\% (UNEP, 2011). However, the importing countries lack the necessary infrastructure for an environmentally sound management of e-waste when these goods reach their end-of-life (UNEP, 2011). The disassembling of transformers or the open burning of the unusable EEE to recover valuable metals is one of the practices that contribute dramatically to the increase in the environmental levels of PCBs (but also of PCDD/Fs and PAHs) (Gioia et al., 2014). Further, biomass burning and the exhaust from obsolete cars and industrial engines may be important contributors to the environmental release of PCBs and PCDD/Fs in Africa (Lammel et al., 2013; Laroo et al., 2012).

In this context, the initiation of monitoring studies of the general population of Africa is imperative. However, the economic, logistic, and idiosyncratic characteristics of African countries make this assessment a challenge. For this reason, immigrant population-based studies can be used to obtain information that would otherwise be very difficult to obtain. In the last decade, immigration to Europe has increased, with Africa being the source of a large number of immigrants. The Canary Islands are a territory of the European Union (Spain) in Africa (100 km off the coast of Morocco, Fig. 1), with a socioeconomic level of development comparable to any other territory of the Union. This has made the archipelago a target of irregular immigration; thus, from 1999 to 2011, over 100,000 immigrants from the African continent are estimated to have arrived by sea to the Canary coast (Rodríguez et al., 2008).

We developed this study because we had an exceptional opportunity to conduct the health assessments of these immigrants. We measured the serum levels of 36 POPs in the voluntary participants from 19 countries of Western and Central Africa, who were enrolled. As far as we know no previous studies have been conducted to assess POP levels in migrants from Africa, and thus this study is the first of its kind. The purpose of the assessment was to obtain a glimpse of the baseline levels of pollution of the inhabitants of this extensive region of the African continent. Based on the collected data we performed analyses of the determinants of their contamination levels to test the hypothesis that the current levels of two main classes of POPs in Western and Central African countries are affected by the degree of socioeconomic development.

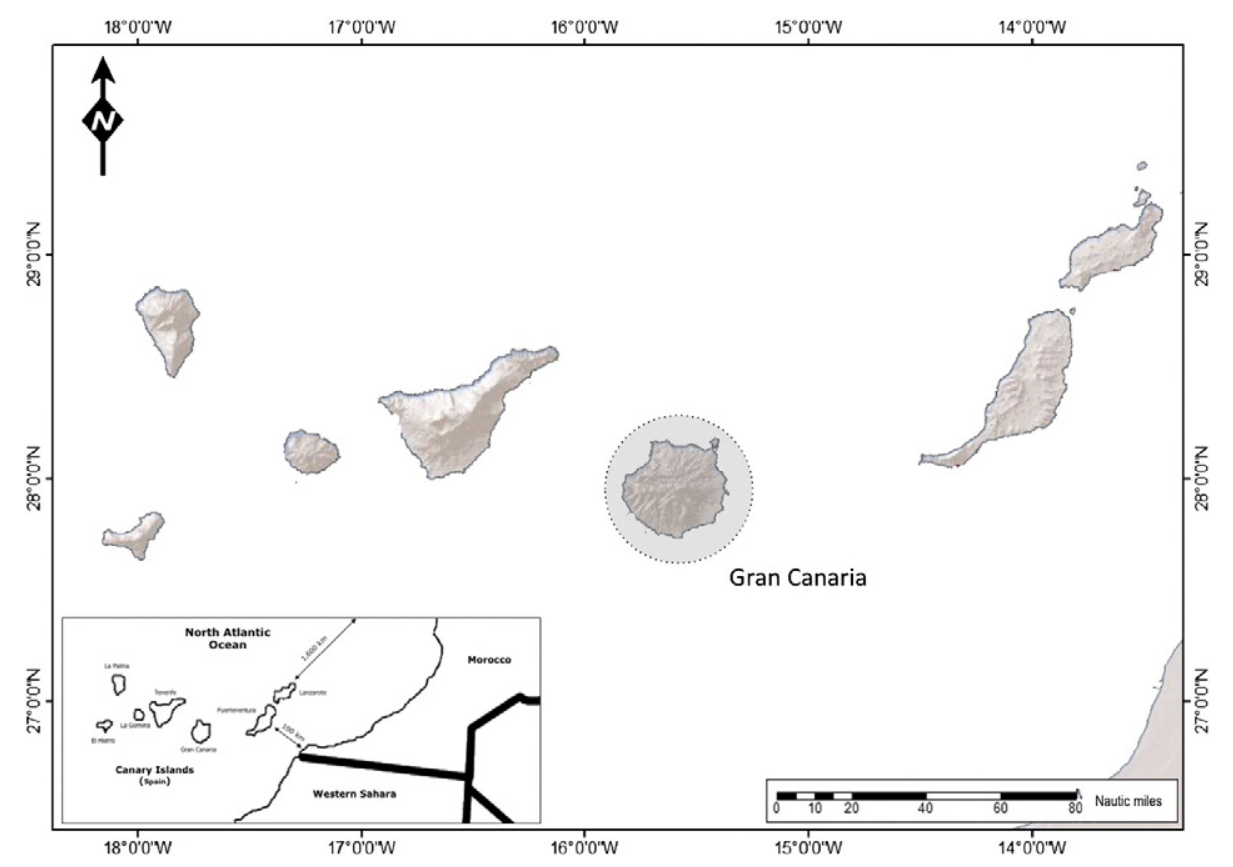

Fig. 1. Map of the Canary Islands. Participants were enrolled in Gran Canaria ( $n=575)$. Inset: the minimum distances from West Africa and mainland Spain are shown. 


\section{Methods}

\subsection{Study population}

The study population consisted of 575 Sub-Saharan African immigrants from all of the 16 Western-African countries and 3 CentralAfrican countries. We sequentially and prospectively recruited the volunteers within the first two months after their arrival on the island of Gran Canaria (Canary Islands, Spain). We recruited people who were temporarily lodged in shelters as part of the general screening for imported diseases. All of the participants provided their written consent for the use of their biological samples for research. They underwent a physical examination to rule out the presence of signs or symptoms of disease. We conducted a supplementary face-to-face interview in English or French following a pre-established questionnaire (de-la-Iglesia-Inigo et al., 2013; Sanz-Pelaez et al., 2008). Trained nurses recorded their heights and weights, and their corresponding body mass index (BMI) was calculated (measured weight [kg] divided by measured height squared $\left[\mathrm{m}^{2}\right]$ ). Height was measured to the nearest $1 \mathrm{~cm}$, and weight was measured to the nearest $0.1 \mathrm{~kg}$. Blood samples were obtained from all of the participants. First, blood samples were analyzed to determine immunological, hematological, biochemical, parasitological, and nutritional parameters. The remaining serum was kept frozen at $-80{ }^{\circ} \mathrm{C}$ until the POPs analysis was performed. The demographic characteristics of the participants and the variables in this study are presented in Table 1.

\subsection{Analytical chemical methods}

We measured the serum levels of 18 OCPs: methoxychlor, p,p'-DDT, p,p'-DDE, p,p'-DDD, hexachlorobenzene (HCB), hexachlorocyclohexane $(\alpha-, \beta-, \gamma-, \delta-H C H)$, aldrin, endrin, dieldrin, heptachlor, cis- and transchlordane, $\alpha$ - and $\beta$-endosulfan, endosulfan-sulfate, and mirex. We also determined 18 PCB congeners, including marker-PCBs (M-PCBs) and dioxin-like PCBs (DL-PCBs): IUPAC numbers \# 28, 52, 77, 81, 101, $105,114,118,123,126,138,153,156,157,167,169,180$, and 189.

The details of sample extraction, validated chromatographic method, and quality control have been previously reported (Camacho et al., 2013; Luzardo et al., 2013). Briefly, samples were subjected to solidphase extraction using Chromabond ${ }^{\circledR}$ C18ec columns (MachereyNagel, Germany) that yielded recoveries in the range of $89-107 \%$. Without further purification steps, the samples were subjected to chromatographic analysis on a Trace GC Ultra coupled with a Quantum Max triple quadrupole mass spectrometer (Thermo Fisher Scientific, Palo Alto, CA) for the quantification of 36 analytes in addition to internal standards and surrogates. The limit of quantification (LOQ) was set at $5 \mathrm{pg} / \mathrm{mL}$ for all the compounds. A zero value was assigned to all the compounds below the limit of detection (LOD), and those compounds below the LOQ were assigned half of the LOQ. The total cholesterol and triglyceride concentrations were used for the lipid adjustment of results, as recommended (Bernert et al., 2007). Therefore, all the results have been expressed in ng/g lipid weight (lw).

\subsection{Statistical analysis.}

We used PASW Statistics v 19.0 (SPSS Inc., Chicago, IL, USA) to manage the database of the study and to perform statistical analyses. Normality was examined using the Kolmogorov-Smirnov test. We used an ANOVA to analyze the normally distributed variables, mainly the anthropometric variables, and the Mann-Whitney and KruskalWallis tests to analyze the non-normally distributed variables. The POP distributions lacked normality and homoscedasticity; therefore, we used non-parametric tests. We used the chi-square test to examine the relationships between the categorical variables. The results were reported as medians and interquartile ranges. Probability levels of less than 0.05 (two tailed) were considered statistically significant. The

\section{Table 1}

Characteristics of participants in the study from Western African countries ( $n=480$ ), Central African countries $(n=95)$, and socio-economic variables used in this study.

\begin{tabular}{|c|c|}
\hline Total samples & $575(100 \%)$ \\
\hline \multicolumn{2}{|l|}{ Anthropometric characteristics } \\
\hline \multicolumn{2}{|l|}{ Gender } \\
\hline Men & $517(89.9 \%)$ \\
\hline Women & $58(10.1 \%)$ \\
\hline \multicolumn{2}{|l|}{ Age (years) } \\
\hline Mean $\pm S D$ & $26.8 \pm 6.6$ \\
\hline Median & 26.0 \\
\hline Range & $15-49$ \\
\hline Participants in quartile 1 ( $Q 1=15-22$ y.o.) & $135(23.5 \%)$ \\
\hline Participants in quartile 2 (Q2 $=22-26$ y.o.) & $136(23.7 \%)$ \\
\hline Participants in quartile 3 ( $\mathrm{Q} 3=26-31$ y.o.) & $145(25.2 \%)$ \\
\hline Participants in quartile 4 (Q4 = 31-49 y.o.) & $159(27.6 \%)$ \\
\hline \multicolumn{2}{|l|}{ BMI } \\
\hline Mean \pm SD & $23.8 \pm 3.5$ \\
\hline Median & 23.7 \\
\hline \multicolumn{2}{|l|}{ Origin } \\
\hline \multicolumn{2}{|l|}{ Western Africa } \\
\hline Benin & $3(0.5 \%)$ \\
\hline Burkina Faso & $4(0.7 \%)$ \\
\hline Cape Verde & $1(0.2 \%)$ \\
\hline Gambia, The & $22(3.8 \%)$ \\
\hline Ghana & $106(18.4 \%)$ \\
\hline Guinea & $41(7.1 \%)$ \\
\hline Guinea Bissau & $15(2.6 \%)$ \\
\hline Ivory Coast & $21(3.7 \%)$ \\
\hline Liberia & $7(1.2 \%)$ \\
\hline Mali & $34(5.9 \%)$ \\
\hline Mauritania & $7(1.2 \%)$ \\
\hline Niger & $1(0.2 \%)$ \\
\hline Nigeria & $109(19.1 \%)$ \\
\hline Saint Tome et Principe & $1(0.2 \%)$ \\
\hline Senegal & $26(4.5 \%)$ \\
\hline Sierra Leona & $79(13.7 \%)$ \\
\hline Togo & $3(0.5 \%)$ \\
\hline \multicolumn{2}{|l|}{ Central Africa } \\
\hline Cameroon & $41(7.1 \%)$ \\
\hline Congo, Republic & $31(5.4 \%)$ \\
\hline Equatorial Guinea & $23(4.0 \%)$ \\
\hline \multicolumn{2}{|l|}{ Habitat } \\
\hline Rural & $246(42.8 \%)$ \\
\hline Urban & $329(57.2 \%)$ \\
\hline \multicolumn{2}{|l|}{ Economic development indicators ${ }^{\text {a }}$} \\
\hline \multicolumn{2}{|l|}{ Gross national income per capita } \\
\hline Low income (<US\$1005) & $213(37.0 \%)$ \\
\hline Lower-middle income (US\$1006-US\$3975) & $339(58.9 \%)$ \\
\hline Upper-middle income (US\$3976-US\$12,275) & $0(0.0 \%)$ \\
\hline High income (>US\$12,276) & $23(4.1 \%)$ \\
\hline \multicolumn{2}{|l|}{ Internet implantation } \\
\hline$<10 \%$ users & $363(63.6 \%)$ \\
\hline$>10 \%$ users & $212(36.4 \%)$ \\
\hline \multicolumn{2}{|l|}{ Telephone users } \\
\hline$<50$ lines/100 people & $202(35.1 \%)$ \\
\hline$>50$ lines/100 people & $373(64.9 \%)$ \\
\hline
\end{tabular}

a These values are referred to the country of origin of the immigrants (UNEP, 2011; World Bank, 2013). The figures in the right column indicate the number and percentage of immigrants, which belonged to these countries.

breakpoints used for economic development variables were the median values of the distribution of those variables between the countries of origin of immigrants.

\subsection{Quality control}

The recoveries of all the analytes were acceptable using this method because in all of the cases, the recoveries were above $74 \%$. All the individual measurements were corrected by the recovery efficiency for each analyte. All the measurements were performed in triplicate, and the values used for calculations were the mean of the three values. In each batch of samples, two controls were included every 12 samples: a reagent blank consisting of a vial containing only cyclohexane and an internal laboratory quality control (QC) consisting of blank 
Table 2

Concentrations of organohalogenated pollutants (median and interquartile range) in serum samples of Western and Central Africa immigrants recently arrived to Gran Canaria (Canary Islands, Spain). Results are expressed in ng/g lw.

\begin{tabular}{|c|c|c|c|c|c|c|c|c|c|c|c|c|c|c|}
\hline & \multirow{3}{*}{$\begin{array}{l}\text { All countries } \\
n=575\end{array}$} & \multicolumn{10}{|c|}{ Western Africa $^{\mathrm{a}}$} & \multicolumn{3}{|c|}{ Central Africa $^{\mathrm{b}}$} \\
\hline & & \multirow{2}{*}{$\begin{array}{l}\mathrm{IC} \\
n=21\end{array}$} & \multirow{2}{*}{$\frac{\mathrm{GM}}{n=22}$} & \multirow{2}{*}{$\frac{\mathrm{GH}}{n=106}$} & \multirow{2}{*}{$\frac{\mathrm{GN}}{n=41}$} & \multirow{2}{*}{$\frac{\mathrm{GB}}{n=15}$} & \multirow{2}{*}{$\frac{\mathrm{ML}}{n=34}$} & \multirow{2}{*}{$\begin{array}{l}\mathrm{NG} \\
n=109\end{array}$} & \multirow{2}{*}{$\frac{S N}{n=26}$} & \multirow{2}{*}{$\frac{\mathrm{SL}}{n=79}$} & \multirow{2}{*}{$\frac{\operatorname{Misc}^{\mathrm{c}}}{n=27}$} & \multirow{2}{*}{$\begin{array}{l}\mathrm{CM} \\
n=41\end{array}$} & \multirow{2}{*}{$\begin{array}{l}\text { CG } \\
n=31\end{array}$} & \multirow{2}{*}{$\frac{\mathrm{GQ}}{n=25}$} \\
\hline & & & & & & & & & & & & & & \\
\hline \multicolumn{15}{|l|}{ OCPs } \\
\hline$\sum$ DDTs $^{d}$ & $\begin{array}{l}294 \\
(124-708)\end{array}$ & $\begin{array}{l}193 \\
(184-396)\end{array}$ & $\begin{array}{l}299 \\
(69-726)\end{array}$ & $\begin{array}{l}207 \\
(69-493)\end{array}$ & $\begin{array}{l}313 \\
(125-967)\end{array}$ & $\begin{array}{l}130 \\
(37-339)\end{array}$ & $\begin{array}{l}248 \\
(62-1503)\end{array}$ & $\begin{array}{l}311 \\
(156-612)\end{array}$ & $\begin{array}{l}118 \\
(23-307)\end{array}$ & $\begin{array}{l}485 \\
(177-685)\end{array}$ & $\begin{array}{l}326 \\
(137-685)\end{array}$ & $\begin{array}{l}523 \\
(221-858)\end{array}$ & $\begin{array}{l}636 \\
(329-1553)\end{array}$ & $\begin{array}{l}385 \\
(64-1404)\end{array}$ \\
\hline$\sum \mathrm{HCH}^{\mathrm{e}}$ & $\begin{array}{l}1 \\
(0-6)\end{array}$ & $\begin{array}{l}1 \\
(0-37)\end{array}$ & $\begin{array}{l}1 \\
(0-3)\end{array}$ & $\begin{array}{l}2 \\
(0-5)\end{array}$ & $\begin{array}{l}1 \\
(0-5)\end{array}$ & $\begin{array}{l}2 \\
(0-9)\end{array}$ & $\begin{array}{l}2 \\
(1-6)\end{array}$ & $\begin{array}{l}2 \\
(0-6)\end{array}$ & $\begin{array}{l}3 \\
(1-7)\end{array}$ & $\begin{array}{l}1 \\
(0-7)\end{array}$ & $\begin{array}{l}0 \\
(0-9)\end{array}$ & $\begin{array}{l}1 \\
(0-2)\end{array}$ & $\begin{array}{l}1 \\
(0-2)\end{array}$ & $\begin{array}{l}1 \\
(0-6)\end{array}$ \\
\hline$\sum$ Cyclodienes $^{\mathrm{f}}$ & $\begin{array}{l}1 \\
(0-6)\end{array}$ & $\begin{array}{l}2 \\
(1-206)\end{array}$ & $\begin{array}{l}17 \\
(1-38)\end{array}$ & $\begin{array}{l}10 \\
(1-50)\end{array}$ & $\begin{array}{l}3 \\
(1-44)\end{array}$ & $\begin{array}{l}10 \\
(1-24)\end{array}$ & $\begin{array}{l}5 \\
(1-56)\end{array}$ & $\begin{array}{l}16 \\
(2-53)\end{array}$ & $\begin{array}{l}1 \\
(0-19)\end{array}$ & $\begin{array}{l}17 \\
(1-72)\end{array}$ & $\begin{array}{l}15 \\
(3-73)\end{array}$ & $\begin{array}{l}7 \\
(0-44)\end{array}$ & $\begin{array}{l}12 \\
(6-38)\end{array}$ & $\begin{array}{l}56 \\
(6-152)\end{array}$ \\
\hline$\sum$ Chlordanes $^{\mathrm{g}}$ & $\begin{array}{l}11 \\
(1-53)\end{array}$ & $\begin{array}{l}0 \\
(0-1)\end{array}$ & $\begin{array}{l}0 \\
(0-2)\end{array}$ & $\begin{array}{l}0 \\
(0-2)\end{array}$ & $\begin{array}{l}0 \\
(0-2)\end{array}$ & $\begin{array}{l}0 \\
(0-2)\end{array}$ & $\begin{array}{l}0 \\
(0-2)\end{array}$ & $\begin{array}{l}0 \\
(0-2)\end{array}$ & $\begin{array}{l}0 \\
(0-1)\end{array}$ & $\begin{array}{l}0 \\
(0-2)\end{array}$ & $\begin{array}{l}1 \\
(0-4)\end{array}$ & $\begin{array}{l}1 \\
(0-3)\end{array}$ & $\begin{array}{l}1 \\
(0-2)\end{array}$ & $\begin{array}{l}2 \\
(0-5)\end{array}$ \\
\hline$\sum \mathrm{OCPs}^{\mathrm{h}}$ & $\begin{array}{l}361 \\
(163-827)\end{array}$ & $\begin{array}{l}322 \\
(194-841)\end{array}$ & $\begin{array}{l}325 \\
(118-743)\end{array}$ & $\begin{array}{l}292 \\
(119-555)\end{array}$ & $\begin{array}{l}351 \\
(148-1016)\end{array}$ & $\begin{array}{l}134 \\
(56-407)\end{array}$ & $\begin{array}{l}281 \\
(117-1558)\end{array}$ & $\begin{array}{l}400 \\
(198-719)\end{array}$ & $\begin{array}{l}124 \\
(49-359)\end{array}$ & $\begin{array}{l}574 \\
(247-968)\end{array}$ & $\begin{array}{l}409 \\
(197-787)\end{array}$ & $\begin{array}{l}556 \\
(254-916)\end{array}$ & $\begin{array}{l}660 \\
(372-1585)\end{array}$ & $\begin{array}{l}558 \\
(126-1351)\end{array}$ \\
\hline \multicolumn{15}{|l|}{ PCBs } \\
\hline$\sum \mathrm{M}-\mathrm{PCBs} \mathrm{s}^{\mathrm{i}}$ & $\begin{array}{l}198 \\
(34-613)\end{array}$ & $\begin{array}{l}28 \\
(3-69)\end{array}$ & $\begin{array}{l}79 \\
(6-298)\end{array}$ & $\begin{array}{l}1343 \\
(10-2889)\end{array}$ & $\begin{array}{l}136 \\
(44-383)\end{array}$ & $\begin{array}{l}116 \\
(47-253)\end{array}$ & $\begin{array}{l}119 \\
(9-225)\end{array}$ & $\begin{array}{l}230 \\
(63-413)\end{array}$ & $\begin{array}{l}75 \\
(18-173)\end{array}$ & $\begin{array}{l}181 \\
(61-363)\end{array}$ & $\begin{array}{l}167 \\
(2-228)\end{array}$ & $\begin{array}{l}92 \\
(45-150)\end{array}$ & $\begin{array}{l}181 \\
(65-326)\end{array}$ & $\begin{array}{l}689 \\
(518-1126)\end{array}$ \\
\hline$\sum D-P_{C B s}{ }^{j}$ & $\begin{array}{l}26 \\
(2-69)\end{array}$ & $\begin{array}{l}0 \\
(0-11)\end{array}$ & $\begin{array}{l}0 \\
(0-21)\end{array}$ & $\begin{array}{l}139 \\
(0-387)\end{array}$ & $\begin{array}{l}11 \\
(0-70)\end{array}$ & $\begin{array}{l}5 \\
(0-62)\end{array}$ & $\begin{array}{l}0 \\
(0-38)\end{array}$ & $\begin{array}{l}10 \\
(3-47)\end{array}$ & $\begin{array}{l}0 \\
(2-37)\end{array}$ & $\begin{array}{l}0 \\
(3-41)\end{array}$ & $\begin{array}{l}0 \\
(0-50)\end{array}$ & $\begin{array}{l}0 \\
(0-28)\end{array}$ & $\begin{array}{l}0 \\
(0-27)\end{array}$ & $\begin{array}{l}72 \\
(32-108)\end{array}$ \\
\hline$\sum \mathrm{PCBs}^{\mathrm{k}}$ & $\begin{array}{l}222 \\
(82-678)\end{array}$ & $\begin{array}{l}28 \\
(3-85)\end{array}$ & $\begin{array}{l}81 \\
(11-309)\end{array}$ & $\begin{array}{l}1530 \\
(568-2943)\end{array}$ & $\begin{array}{l}124 \\
(48-390)\end{array}$ & $\begin{array}{l}137 \\
(54-256)\end{array}$ & $\begin{array}{l}141 \\
(66-229)\end{array}$ & $\begin{array}{l}255 \\
(85-439)\end{array}$ & $\begin{array}{l}78 \\
(25-182)\end{array}$ & $\begin{array}{l}181 \\
(99-374)\end{array}$ & $\begin{array}{l}133 \\
(65-283)\end{array}$ & $\begin{array}{l}117 \\
(59-164)\end{array}$ & $\begin{array}{l}181 \\
(92-356)\end{array}$ & $\begin{array}{l}887 \\
(621-1230)\end{array}$ \\
\hline$\sum$ TEQs $^{1, \mathrm{~m}}$ & $\begin{array}{l}7.8 \\
(0.6-25.7)\end{array}$ & $\begin{array}{l}0 \\
(0-2.8)\end{array}$ & $\begin{array}{l}0 \\
(0-26.3)\end{array}$ & $\begin{array}{l}41.7 \\
(0-58.1)\end{array}$ & $\begin{array}{l}2.7 \\
(0-21)\end{array}$ & $\begin{array}{l}2.1 \\
(0-18.7)\end{array}$ & $\begin{array}{l}0 \\
(0-11.4)\end{array}$ & $\begin{array}{l}3.1 \\
(1.1-14.1)\end{array}$ & $\begin{array}{l}0 \\
(0.6-11.1)\end{array}$ & $\begin{array}{l}0 \\
(0.9-12.3)\end{array}$ & $\begin{array}{l}0 \\
(0-14.9)\end{array}$ & $\begin{array}{l}0 \\
(0-8.4)\end{array}$ & $\begin{array}{l}0 \\
(0-8.1)\end{array}$ & $\begin{array}{l}21.6 \\
(9.6-32.4)\end{array}$ \\
\hline
\end{tabular}

a Western African countries: Ivory Coast (IC); The Gambia (GM); Ghana (GH); Guinea (GN); Guinea Bissau (GB); Mali (ML); Nigeria (NG); Senegal (SN); Sierra Leone (SL); Miscellanea (Misc),

Central African countries: Cameroon (CM); Congo Republic (CG); Equatorial Guinea (GQ).

d $\sum$ MDTs: sum of p,p'-DDT, p, p'-DDE, and p,p'-DDD.

e $\sum$ HCHs: sum of isomers $\alpha-, \beta-, \gamma-$, and $\delta$ - of hexachlorocyclohexane.

f $\sum$ Cyclodienes: sum of aldrin, dieldrin, endrin, endosulfan $\alpha$, endosulfan $\beta$, and endosulfan sulfate.

g $\sum$ Chlordanes: sum of cis chlordane and trans chlordane.

h $\sum$ OCPs: sum of all 18 organochlorine pesticides.

$\sum$ M-PCBs: sum of marker PCBs (\#28, 52, 101, 118, 138, 153, 180).

$\sum$ DL-PCBs: sum of dioxin-like PCBs (\#77, 81, 105, 114, 118, 123, 126, 156, 157, 167, 169, 189).

$k$ PCBs: sum of all 18 PCB congeners.

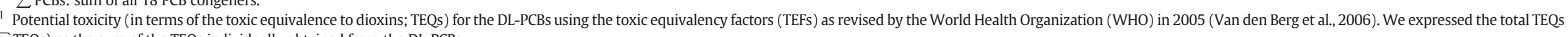

( $\sum$ TEQs) as the sum of the TEQs individually obtained from the DL-PCBs.

$\mathrm{m}$ Expressed in pg g- 1 fat. 
serum (Lyophilized human serum, Medidrug Basis Line, Medichem, Germany) spiked at $20 \mu \mathrm{g} / \mathrm{kg}$ of each of the analytes that were processed using the same method as the samples. The batch analyses were considered valid when the values of the analytes in the QC were within $15 \%$ of the deviation of the theoretical value.

\section{Results}

\subsection{Assessment of serum concentrations of POPS}

We found a high degree of variability in the concentrations and frequencies of POP levels. Table 2 summarizes the results by chemical classes (detailed results of all the analytes have been included as Supplementary Tables 1 and 2). It is noteworthy that all of the analytes included in the study were detected, although the frequencies of detection were highly variable. Thus, the most frequently detected compound was p, $\mathrm{p}^{\prime}-\mathrm{DDE}$ (100\% of the samples); its parent compound (p,p'-DDT) was detected in $72.2 \%$ of the samples. PCBs \#28, 138, 153, and 180 were also detected in $>70 \%$ of the samples. The frequencies of the other POPs ranged from $2.7 \%$ to $64.6 \%$. The pesticides that contributed more to the total OCP ( $\sum$ OCPs) levels were DDTs ( $\left.81.2 \%\right)$, and the PCB congeners that contributed more to the total PCB ( $\sum$ PCBs) levels were M-PCBs (89.8\%). These main contributors did not change when the results were analyzed according to the country of origin.

The pattern of contamination varied among the countries in a statistically significant manner for both the $\sum$ OCPs $(p<0.0005)$ and $\sum$ PCBs $(p<0.0001)$ (Supplementary Fig. 1$)$. Thus, participants from the Congo Republic and Sierra Leona had the highest levels of contamination by the OCPs (median $660 \mathrm{ng} / \mathrm{g}$ lw and $574 \mathrm{ng} / \mathrm{g}$ lw, respectively), and those from Guinea Bissau and Senegal had the lowest levels (median $134 \mathrm{ng} / \mathrm{g}$ lw and $124 \mathrm{ng} / \mathrm{g}$ lw, respectively). The immigrants from Ghana and Equatorial Guinea had the highest median concentrations of PCBs (1530 ng/g lw and $887 \mathrm{ng} / \mathrm{g}$ lw, respectively), whereas those from the Ivory Coast ( $28 \mathrm{ng} / \mathrm{g} \mathrm{lw}$ ) and Senegal ( $78 \mathrm{ng} / \mathrm{g} \mathrm{lw}$ ) had the lowest concentrations.

Fig. 2 presents the summary of the results by region: WesternAfrican vs. Central-African immigrants. We found that the levels of $\sum$ OCPs were higher in the Central-African immigrants (median = $632 \mathrm{ng} / \mathrm{g} \mathrm{lw}$ ) than in the Western-African immigrants (451 ng/g lw) $(p<0.05)$. However, the $\sum$ PCB levels were much higher in the Western-African immigrants (262 ng/g lw) than in the Central-African immigrants $(136 \mathrm{ng} / \mathrm{g} \mathrm{lw})(p<0.0001)$. The chemical class differences remained statistically significant for the $\sum$ DDTs $(p<0.005), \sum \mathrm{HCHs}$ $(p<0.05)$, M-PCBs $(p<0.0001)$, and DL-PCBs $(p<0.001)$ (data not shown in Fig. 2).

\subsection{Anthropometric determinants of POP contamination}

We examined the effects of age, sex, and BMI on the levels of POPs. There was no influence of sex or BMI on the levels of pollutants. However, there was an age effect in which the levels of $\sum$ OCPs were higher in the upper quartile $(\mathrm{Q} 4, p<0.001)$. There was also a regional effect when we analyzed the entire sample and for Q3 in Central-African immigrants when the sample was analyzed by region $(p<0.05)$. We also observed a trend of increased $\sum$ PCB levels with increased age, with the median level in Q3 significantly higher than the median levels of Q1 and Q2 $(p<0.05)$, but lower than the median level of Q4 $(p<0.05)$. This trend also was present in the regional analyses, with significantly higher median levels among the Western-African immigrants in Q4 ( $p<0.001)$ (Supplementary Fig. 2).

\subsection{Socioeconomic determinants of POP contamination}

First, we studied the effects of the gross national income per capita (GNI) (World Bank, 2013) on the levels of POPs in the immigrants. We found a decreasing trend for $\sum$ OCPs and an increasing trend for $\sum$ PCBs
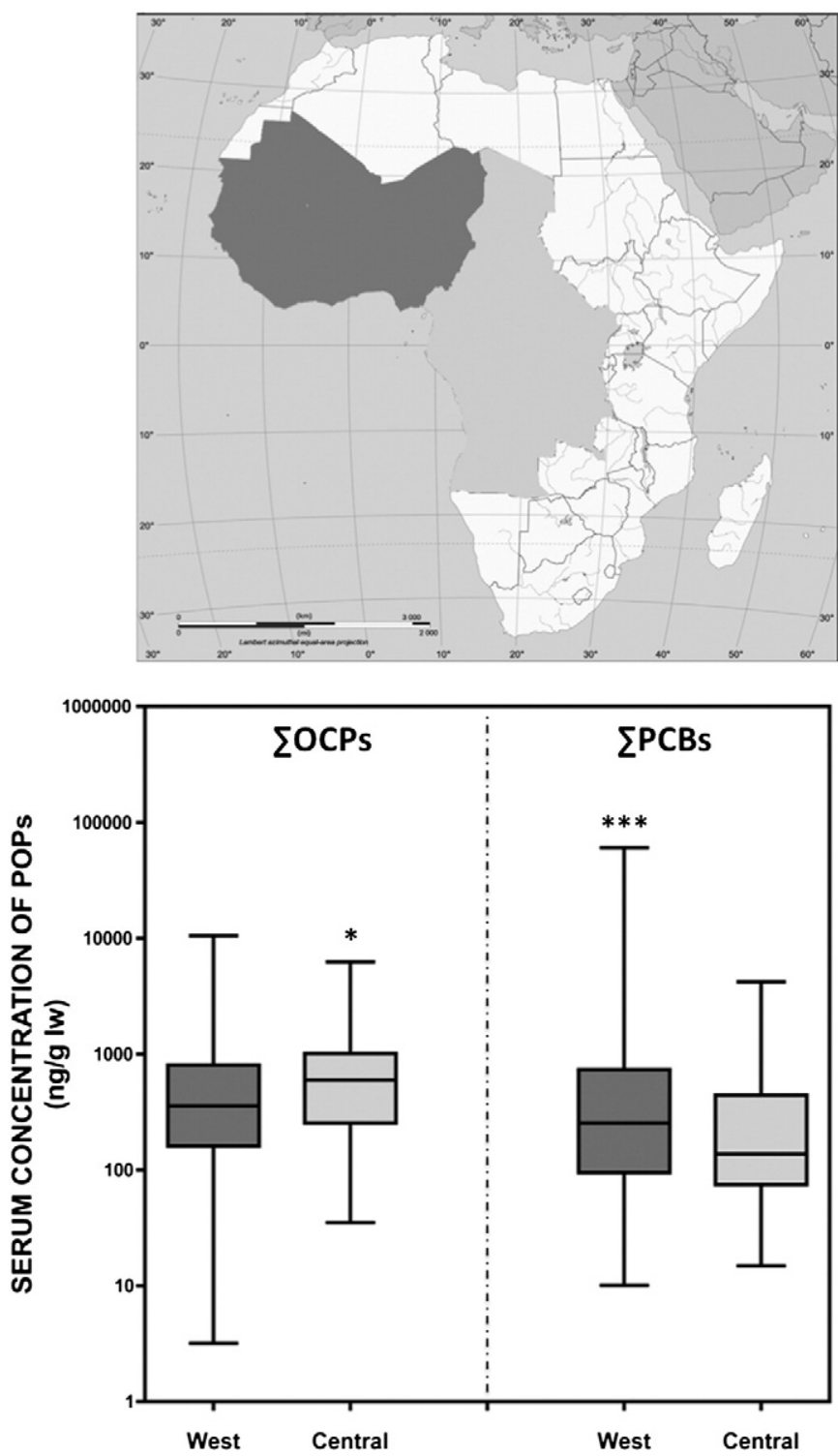

Fig. 2. Box plots indicating the comparison of the levels of OCPs (left) and PCBs (right) of immigrants grouped by region of origin: West Africa vs. Central Africa. The line inside the box represents the median, the bottom and top of the box are the first and third quartiles of the distribution, and the lines extending vertically from the boxes indicate the variability outside the upper and lower quartiles.

with increasing income (Fig. 3). Thus, immigrants from countries with low GNIs had significantly higher levels of $\sum$ OCPs (379 ng/g lw) than those from countries with middle GNIs (341 ng/g lw) $(p<0.01)$, and high-GNIs (199 ng/g lw) $(p<0.005)$. On the contrary, the $\sum$ PCB levels of immigrants from low-GNI countries were much lower $(155 \mathrm{ng} / \mathrm{g} \mathrm{lw})$ than those from middle-GNI (350 ng/g lw) $(p<0.001)$, and high-GNI countries $(726 \mathrm{ng} / \mathrm{g} \mathrm{lw})(p<0.0001)$. People from the upper-middle GNI countries did not participate in this study.

We also examined the effect of the type of residential area (rural vs. urban) in which the immigrants lived in their country of origin, on their POP levels. No significant differences were found in the analysis of the overall sample, or by countries or area. However, when we grouped the immigrants according to the GNI of their countries of origin, we found that the levels of $\sum$ OCPs were significantly higher in people from rural areas of lower-GNI-countries (412 ng/g lw) that those from cities (317 ng/g lw [163-843] $(p<0.05)$. In contrast, the people from urban areas of low-GNI countries had higher levels of $\sum$ PCBs 


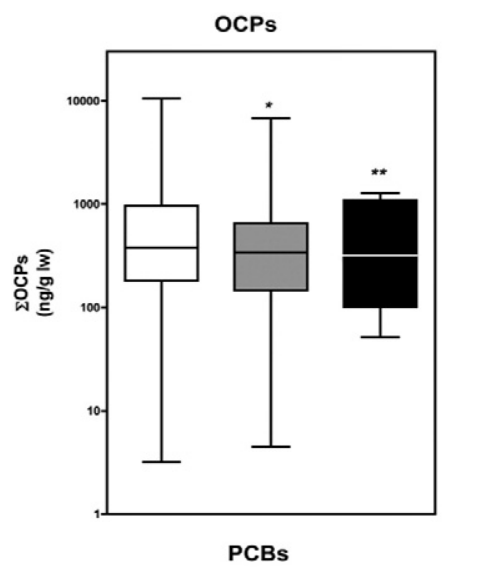

\begin{tabular}{lclccc}
\hline Low income & GNI & Middle Income & GNI & High income & GNI \\
LIBERIA & $210 \$$ & SENEGAL & $1080 \$$ & EQUATORIAL GUINEA & $13720 \$$ \\
SIERRA LEONA & $340 \$$ & NIGERIA & $1170 \$$ & & \\
NIGER & $360 \$$ & COSTA DE MARFIL & $1170 \$$ & & \\
GUINEA CONAKRY & $390 \$$ & CAMEROON & $1200 \$$ & & \\
BURKINA FASSO & $550 \$$ & GHANA & $1250 \$$ & & \\
TOGO & $550 \$$ & CONGO & $2240 \$$ & & \\
GUINEA BISSAU & $580 \$$ & CABO VERDE & $3280 \$$ & & \\
MALI & $600 \$$ & & & & \\
GAMBIA & $610 \$$ & & & & \\
BENIN & $780 \$$ & & & &
\end{tabular}
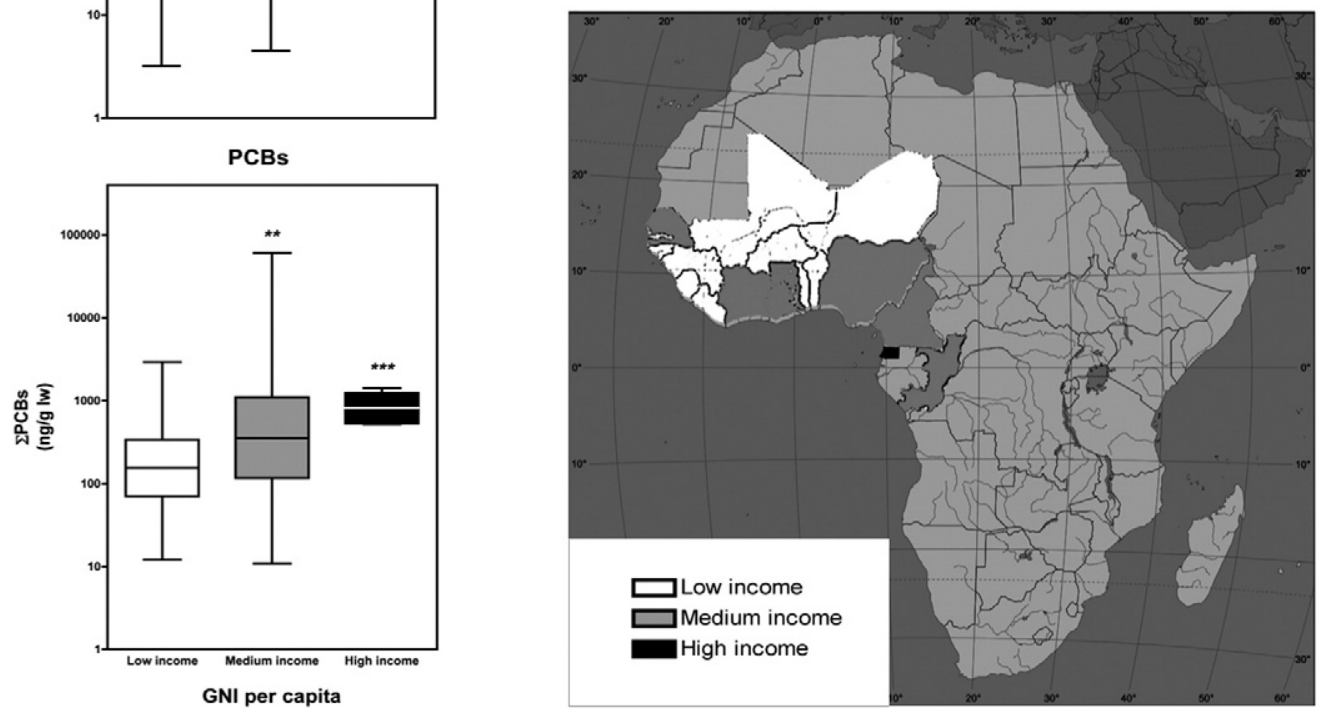

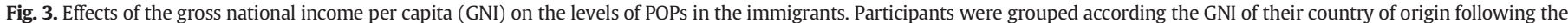

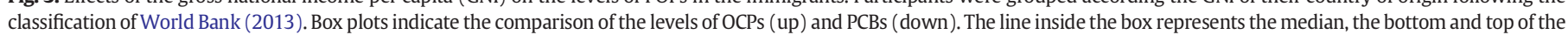
box are the first and third quartiles of the distribution, and the lines extending vertically from the boxes indicate the variability outside the upper and lower quartiles.
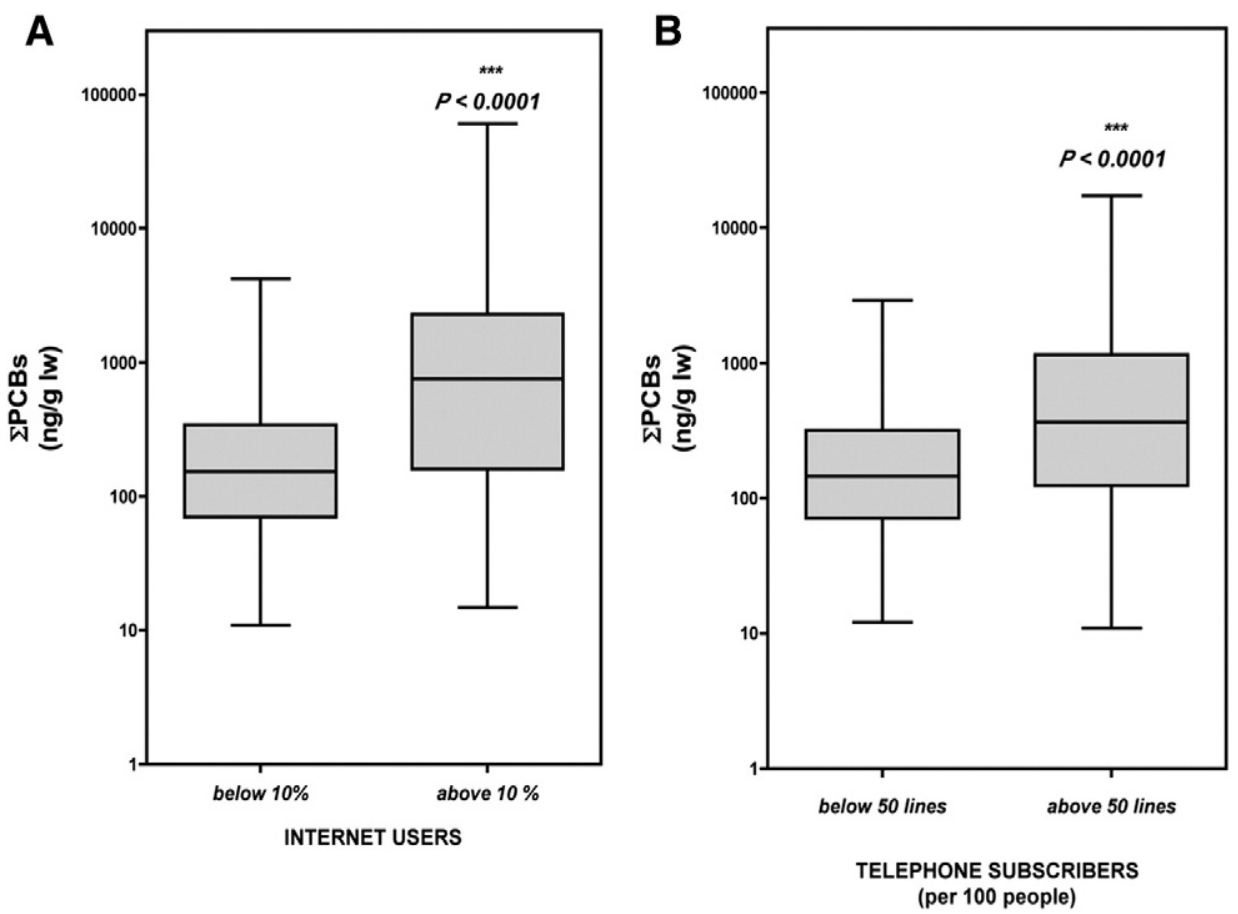

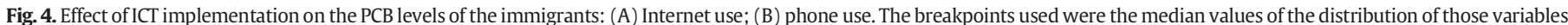

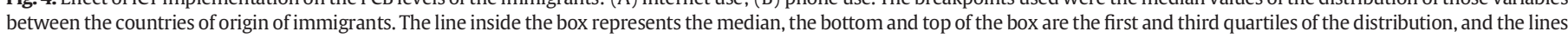
extending vertically from the boxes indicate the variability outside the upper and lower quartiles. 

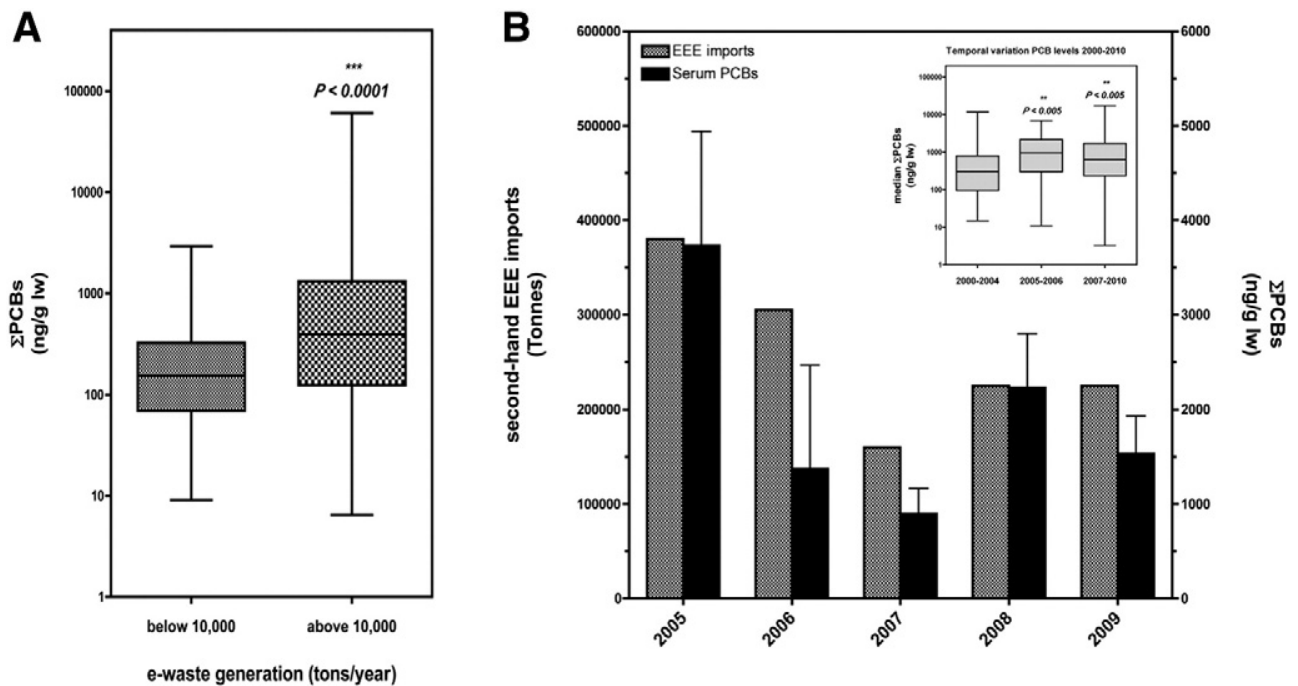

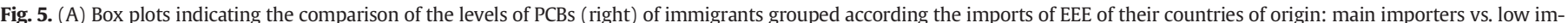

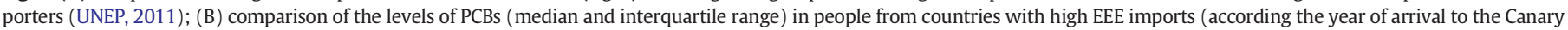

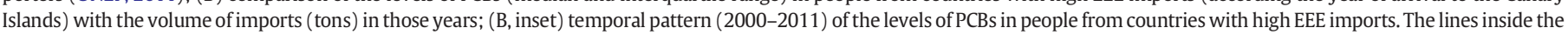

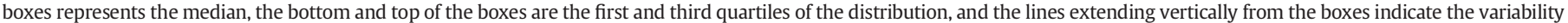
outside the upper and lower quartiles.

(375 ng/g lw) than those from rural areas (129 ng/g lw, $p<0.005$ ). None of these differences was observed in immigrants from middleor high-GNI countries.

\subsection{ICT implementation and POP contamination}

Finally, we explored the effect of ICT implementation on the POP levels of the immigrants (Fig. 4). We found no differences between the two major ICT indicators by country (percentage of Internet users, and number of telephone line subscribers per 100 inhabitants) on the $\sum$ OCP levels of the immigrants. However, we found strong associations between these variables and levels of $\sum$ PCBs. Panel A (left) shows that immigrants from countries with more than $10 \%$ Internet users among three populations had significantly higher levels of $\sum$ PCBs ( $756 \mathrm{ng} / \mathrm{g} \mathrm{lw}$ ) than those from the countries that had a low rate of Internet use $(154 \mathrm{ng} / \mathrm{g} \mathrm{lw})(p<0.0001)$. In keeping with this finding, the levels of $\sum$ PCBs were significantly higher in the immigrants from countries with more than 50 phone subscribers/100 inhabitants ( $365 \mathrm{ng} / \mathrm{g} \mathrm{lw}$ ) than in those from countries with fewer telephone users (145 ng/g lw) $(p<0.0001)$.

\subsection{Second-hand EEE imports and POP contamination}

We collapsed the groups of immigrants from the countries that are the main importers of second-hand EEE into one group (Nigeria, Ghana, Ivory Coast, Liberia, and Benin (UNEP, 2011)), and compared its POP levels to the other countries. We did not find an overall association with the $\sum$ OCP levels, but the immigrants' $\sum$ PCB levels were strongly associated with the imports of second-hand EEE by their country of origin (393 ng/g lw vs. $154 \mathrm{ng} / \mathrm{g}$ lw, $p<0.0001$ ) (Fig. 5, left panel). Moreover, the highest levels of $\sum$ PCBs in people from those countries were exhibited by the immigrants that arrived in the Canaries during the years when this trade was more intense (UNEP, 2011) (Fig. 5, right, main body). In any case, a statistically significant increase in the levels of PCBs was recorded from 2005 onwards in these immigrants (Fig. 5, right, inset) $(p<0.005)$.

\section{Discussion}

Several studies on environmental samples have reported increased levels of many types of POPs in Africa, such as OCPs, PCBs, or polycyclic aromatic hydrocarbons (Adu-Kumi et al., 2012; Asante et al., 2013; Garrison et al., 2014; Gioia et al., 2014; Klanova et al., 2009; Ndiaye et al., 2012; Ssebugere et al., 2013). However, there are few studies of humans to confirm that this finding represents a growing trend. To date, the only study on temporal changes found a downward trend over time (1991-2007) in both OCP and PCB levels (Linderholm et al., 2010). Nevertheless, the results of the present investigation indicate that the increasing pollution levels in the African environment are resulting in increased levels in humans. Thus, we have found that immigrants from some West African countries who arrived in the Canary Islands after 2005 had significantly higher levels of PCBs than those who reached the islands earlier. This finding is consistent with the results of a study of Ghana's population (Asante et al., 2011) that found higher levels of PCBs and PCDD/Fs in 2009 than in 2004 (in breast milk). Regardless of the temporal pattern, our results are quantitatively comparable with those of other studies of Africans (Chikuni et al., 1997; Ejobi et al., 1996; Ennaceur et al., 2008; Kinyamu et al., 1998; Linderholm et al., 2010; Pieters and Focant, 2014). In all of these studies, high concentrations of OCPs and PCBs have been found in human samples (serum OCPs from 310 to $3400 \mathrm{ng} / \mathrm{g}$ lw and serum PCBs from 68 to $230 \mathrm{ng} / \mathrm{g} \mathrm{lw}$ ). Even, when we used the toxic equivalency factors (TEFs) as revised by the World Health Organization (WHO) in 2005 (Van den Berg et al., 2006) to obtain the potential toxicity (in terms of the toxic equivalence to dioxins; TEQs) for the DL-PCBs, our results were also similar to those reported in the only publication to date that has employed such a transformation in an African population $(2.8 \mathrm{pg} / \mathrm{g} \mathrm{lw}$ for South African Tswana population) (Pieters and Focant, 2014). Our results, as well as those reported in other publications, seem to be logical in the case of OCPs, since these compounds have been historically used (and even abused) in Africa (Mansour, 2004). However, the case of PCBs is striking because the sources of these compounds have historically been of little use on this continent. However, the levels found in the Africans in this study are similar to, or even higher than, those reported in European and US populations (around 150-200 ng/g lw) (Asante et al., 2011). Since the production and marketing of these products ceased around the world in the mid-1980s, the high levels seem to be the result of the introduction of new sources of these compounds in Africa. According Gioia et al. (2014) emerging sources of PCBs in Africa include (1) increasing of e-waste as a consequence of illegal recycling and treatment of EEE; (2) oil leaching into the environment as a consequence of disassembling of transformers and their inappropriate 
disposal; (3) open burning of EEE and wires to obtain valuable materials and (4) ship wreckage.

This study included people from all of the countries of Western African and from the three westernmost countries of Central Africa. Although both regions occupy a similar area (approximately 5.5 million sq $\mathrm{km}$ ), the population density is very different between them. In West Africa, which includes some of the most populated cities in Africa, the population density is more than twice that of Central Africa, where the population is more dispersed and follows a more rural lifestyle (50.24 vs. 20.53 people per sq km) (World Bank, 2013). This could explain the results observed in this study, in which the OCP levels are significantly higher in the immigrants from Central Africa, and PCB levels are much higher in immigrants from West Africa (Fig. 2).

It has been widely reported in the literature that concentrations of POPs are often associated with age, BMI, and sex, as well as with socioeconomic variables, such as educational level and occupational social class (Gasull et al., 2013). Regarding anthropometric variables, because the study population was homogeneous in terms of BMI and sex $(89.9 \%$ men), we found a clear association of POPs with only age. Sex differences have been usually documented by other authors, but in this case, although the number of volunteers is high, the sex ratio is highly unbalanced and probably the $\mathrm{n}$ is not large enough data to detect these differences. However, stronger associations were found with the socioeconomic variables, especially the economic development indicators. In fact, we found that immigrants from the poorest countries exhibited significantly higher levels of contamination by OCPs but much lower levels of contamination by PCBs than those from higher income countries. Moreover, immigrants from the urban areas of the lowincome countries had more contamination from PCBs, indicating that the pollution levels are closely related to lifestyle. Emblematic of the economic growth of Sub-Saharan Africa is the implementation of ICT, with more that $80 \%$ of urban Africans now having access to cell phones and more than 89 million Internet users (World Bank, 2013). This trend has led to an unprecedented volume in the production and usage of consumer EEE, especially personal computers, mobile phones, and TV sets. However, there is a great difference in access to ICT between developed and developing countries, and to bridge this "digital divide," imports of second hand digital equipment from developed countries have increased tremendously (UNEP, 2011). Nevertheless, it is unclear how many of these EEE imports were able to function for a reasonable time after being sold, so we suspect that many of these second-hand goods could be considered e-waste (Schmidt, 2006). The short lifespan of this equipment indicates that large amounts of e-waste are generated at a high rate, so it is estimated that the top 5 importers of EEE (Nigeria, Ghana, Ivory Coast, Benin, and Liberia) are generating more than one million tons of e-waste per year (UNEP, 2011). The findings of our study suggest that both the ICT implementation and the second-hand imports of EEE have a strong influence on the levels of contamination by PCBs in the general population of these countries, and consequently, the adverse health effects associated with them. The explanation for this marked impact is probably related to the informal way that the e-waste is addressed in most African countries, where the practices of manual collection and dismantling predominate, and open burning to recover metals and open dumping of residual fractions are the norm (Gioia et al., 2014; UNEP, 2011).

\section{Conclusions}

This is the first study to report the levels of contamination by POPs in the population of a large part of the African continent, covering 19 countries from two distinct regions. We found numerous associations indicating that the rapid economic development experienced by many of these countries has a clear relationship with the pollution levels of the inhabitants. It is true that the study population is not representative of the general population of these countries because the long distance and the difficulties these people faced to immigrate to a European territory introduced a significant bias in the study population (which are mostly young and healthy males). However, we believe that this bias does not detract from the study because the results provide an overview of the determinants of chemical pollution in the most productive segment of the population of the Western and Central African countries. The risk that many POPs pose to human health can interact with the fragile health status and chronic poverty of a large proportion of the African population in the development of many diseases. This situation may be a serious problem if the levels of these contaminants continue to increase in this continent. Furthermore, it is well known that these pollutants do not respect borders, so improper handling of $\mathrm{e}$-waste in these countries can produce a widespread increase in the burden of these contaminants. Therefore, measures should be developed by the international community, together with the governments of African countries, for the proper handling of these legacy pollutants.

Supplementary data to this article can be found online at http://dx. doi.org/10.1016/j.scitotenv.2014.07.124.

\section{Competing financial interest declaration}

There are no actual or potential conflicts of interest to declare for any author.

\section{Acknowledgments}

The authors thank Mrs. María de los Reyes Suárez Hanna for her technical assistance.

\section{References}

Adu-Kumi S, Kares R, Literak J, Boruvkova J, Yeboah PO, Carboo D, et al. Levels and seasona variations of organochlorine pesticides in urban and rural background air of southern Ghana. Environ Sci Pollut Res Int 2012;19:1963-70.

Asante KA, Adu-Kumi S, Nakahiro K, Takahashi S, Isobe T, Sudaryanto A, et al. Human exposure to PCBs, PBDEs and HBCDs in Ghana: temporal variation, sources of exposure and estimation of daily intakes by infants. Environ Int 2011;37:921-8.

Asante KA, Takahashi S, Itai T, Isobe T, Devanathan G, Muto M, et al. Occurrence of halogenated contaminants in inland and coastal fish from Ghana: levels, dietary exposure assessment and human health implications. Ecotoxicol Environ Saf 2013;94:123-30.

Bergman A, Heindel JJ, Jobling S, Kidd KA, Zoeller RT. World Health Organization: State of the Science of Endocrine Disrupting Chemicals-2012. Journal 2012 http://www. unep.org/pdf/EDCs_Summary_for_DMs_Jan24.pdf. [Available at].

Bernert JT, Turner WE, Patterson Jr DG, Needham LL. Calculation of serum "total lipid" concentrations for the adjustment of persistent organohalogen toxicant measurements in human samples. Chemosphere 2007;68:824-31.

Camacho M, Luzardo OP, Boada LD, Lopez Jurado LF, Medina M, Zumbado M, et al. Potential adverse health effects of persistent organic pollutants on sea turtles: evidences from a cross-sectional study on Cape Verde loggerhead sea turtles. Sci Total Environ 2013;458-460C:283-9.

Chikuni O, Nhachi CF, Nyazema NZ, Polder A, Nafstad I, Skaare JU. Assessment of environmental pollution by PCBs, DDT and its metabolites using human milk of mothers in Zimbabwe. Sci Total Environ 1997;199:183-90.

de-la-Iglesia-Inigo S, Carranza-Rodriguez C, Ropero-Gradilla P, Gonzalez-Fernandez FA, Molero-Labarta T, Hemmersbach-Miller M, et al. Red blood cell disorders in recently arrived African immigrants to Gran Canaria, Spain. Trans R Soc Trop Med Hyg 2013; 107:91-7.

Ejobi F, Kanja LW, Kyule MN, Muller P, Kruger J, Latigo AA. Organochlorine pesticide residues in mothers' milk in Uganda. Bull Environ Contam Toxicol 1996;56:873-80.

El-Shahawi MS, Hamza A, Bashammakh AS, Al-Saggaf WT. An overview on the accumulation, distribution, transformations, toxicity and analytical methods for the monitoring of persistent organic pollutants. Talanta 2010;80:1587-97.

Ennaceur S, Gandoura N, Driss MR. Distribution of polychlorinated biphenyls and organochlorine pesticides in human breast milk from various locations in Tunisia: levels of contamination, influencing factors, and infant risk assessment. Environ Res 2008; 108:86-93.

Garrison VH, Majewski MS, Foreman WT, Genualdi SA, Mohammed A, Massey Simonich SL. Persistent organic contaminants in Saharan dust air masses in West Africa, Cape Verde and the eastern Caribbean. Sci Total Environ 2014:468-469:530-43.

Gasull M, Pumarega J, Rovira G, Lopez T, Alguacil J, Porta M. Relative effects of educational level and occupational social class on body concentrations of persistent organic pollutants in a representative sample of the general population of Catalonia, Spain. Environ Int 2013;60:190-201.

Gioia R, Akindele AJ, Adebusoye SA, Asante KA, Tanabe S, Buekens A, et al. Polychlorinated biphenyls (PCBs) in Africa: a review of environmental levels. Environ Sci Pollut Res Int 2014;21(10):6278-89. 
Jarvis IW, Dreij K, Mattsson A, Jernstrom B, Stenius U. Interactions between polycyclic aromatic hydrocarbons in complex mixtures and implications for cancer risk assessment. Toxicology 2014;321C:27-39.

Kim SK, Yoon J. Chronological trends of emission, environmental level and human exposure of POPs over the last 10 years (1999-2010) in Korea: implication to science and policy. Sci Total Environ 2014;470-471:1346-61.

Kinyamu JK, Kanja LW, Skaare JU, Maitho TE. Levels of organochlorine pesticides residues in milk of urban mothers in Kenya. Bull Environ Contam Toxicol 1998;60:732-8.

Klanova J, Cupr P, Holoubek I, Boruvkova J, Pribylova P, Kares R, et al. Monitoring of persistent organic pollutants in Africa. Part 1: passive air sampling across the continent in 2008. J Environ Monit 2009;11:1952-63.

Kortenkamp A. Ten years of mixing cocktails: a review of combination effects of endocrine-disrupting chemicals. Environ Health Perspect 2007;115(Suppl. 1): 98-105.

Lammel G, Heil A, Stemmler I, Dvorska A, Klanova J. On the contribution of biomass burning to POPs (PAHs and PCDDs) in air in Africa. Environ Sci Technol 2013;47: 11616-24.

Laroo CA, Schenk CR, Sanchez LJ, McDonald J, Smith PL. Emissions of PCDD/Fs, PCBs, and PAHs from legacy on-road heavy-duty diesel engines. Chemosphere 2012;89: 1287-94.

Lauby-Secretan B, Loomis D, Grosse Y, El Ghissassi F, Bouvard V, Benbrahim-Tallaa L, et al. Carcinogenicity of polychlorinated biphenyls and polybrominated biphenyls. Lancet Oncol 2013;14:287-8

Linderholm L, Biague A, Mansson F, Norrgren H, Bergman A, Jakobsson K. Human exposure to persistent organic pollutants in West Africa-a temporal trend study from Guinea-Bissau. Environ Int 2010;36:675-82.

Luzardo OP, Ruiz-Suarez N, Almeida-Gonzalez M, Henriquez-Hernandez LA, Zumbado M, Boada LD. Multi-residue method for the determination of 57 persistent organic pollutants in human milk and colostrum using a QuEChERS-based extraction procedure. Anal Bioanal Chem 2013;405(29):9523-36.

Mannetje A, Coakley J, Bridgen P, Brooks C, Harrad S, Smith AH, et al. Current concentrations, temporal trends and determinants of persistent organic pollutants in breast milk of New Zealand women. Sci Total Environ 2013;458-460:399-407.

Mansour SA. Pesticide exposure-Egyptian scene. Toxicology 2004;198:91-115.

Ndiaye A, Sanchez W, Durand JD, Budzinski H, Palluel O, Diouf K, et al. Multiparametric approach for assessing environmental quality variations in West African aquatic ecosystems using the black-chinned tilapia (Sarotherodon melanotheron) as a sentinel species. Environ Sci Pollut Res Int 2012;19:4133-47.
Nost TH, Breivik K, Fuskevag OM, Nieboer E, Odland JO, Sandanger TM. Persistent organic pollutants in Norwegian men from 1979 to 2007: intraindividual changes, ageperiod-cohort effects, and model predictions. Environ Health Perspect 2013;121: 1292-8.

Pieters R, Focant JF. Dioxin, furan and PCB serum levels in a South African Tswana population: comparing the polluting effects of using different cooking and heating fuels. Environ Int 2014;66:71-8.

Rodríguez C, Nuñez SPG, Rodríguez I, Mahtani V, Hernández MA, et al Características de la asistencia sanitaria a la llegada de inmigrantes africanos a las Islas Canarias. Emergencias 2008;20:411-8.

Ryan JJ, Rawn DF. Polychlorinated dioxins, furans (PCDD/Fs), and polychlorinated biphenyls (PCBs) and their trends in Canadian human milk from 1992 to 2005. Chemosphere 2014;102:76-86.

Safe S. Polychlorinated biphenyls (PCBs), dibenzo-p-dioxins (PCDDs), dibenzofurans (PCDFs), and related compounds: environmental and mechanistic considerations which support the development of toxic equivalency factors (TEFs). Crit Rev Toxicol 1990;21:51-88

Sanz-Pelaez O, Santana-Rodriguez E, Maroto AA, Carranza-Rodriguez C, Pisos-Alamo E, Perez-Arellano JL. Helicobacter pylori and cagA seroprevalence in sub-Saharan inmigrants recently arrived to Gran Canaria (Spain). Scand J Infect Dis 2008;40: 756-8.

Schmidt CW. Unfair trade: e-waste in Africa. Environ Health Perspect 2006:114:a232-5.

Ssebugere P, Kiremire BT, Henkelmann B, Bernhoft S, Kasozi GN, Wasswa J, et al. PCDD/Fs and dioxin-like PCBs in fish species from Lake Victoria, East Africa. Chemosphere 2013;92:317-21.

UNEP. Where are WEEE in Africa? Findings from the Basel Convention e-waste Africa programme Secretariat of the Basel Convention; 2011.

Van den Berg M, Birnbaum LS, Denison M, De Vito M, Farland W, Feeley M, et al. The 2005 World Health Organization reevaluation of human and Mammalian toxic equivalency factors for dioxins and dioxin-like compounds. Toxicol Sci 2006;93:223-41.

WHO. Health risks of persistent organic pollutants from long-range transboundary air pollution. Journal 2003 http://www.euro.who.int/_data/assets/pdf_file/0009/ 78660/e78963.pdf. [Available at]

World Bank. Africa Stockpiles Programme-Project 1. 2014. World Bank; 2012.

World Bank. Africa Development Indicators 2012/13. Journal 2013 http://www. worldbank.org/en/region/afr/publication/africa-development-indicators-2012-13. [Available at]. 